\title{
THE FINANCIAL STRUCTURE INFLUENCE ON NET PROFIT
}

\author{
Baciu (Boanta) Rodica \\ Brezeanu Petre ${ }^{2}$ \\ Adrian Simon ${ }^{3}$
}

DOI: https://doi.org/10.31410/ERAZ.2019.207

\begin{abstract}
Financial structure is one of the most complex areas of financial decision making due to its interrelationship with other financial decisions variables. Decision related to financial structure is important because it directly affects the profitability of the organization. The purpose of this paper is to empirically examine the impact of capital structure on net profit for all companies active in the wholesale of motor vehicle parts and accessories in Romania (NACE 4531), with extended financial statements over a 10 years period from 2008 to 2017. In this study, the company's financial structure, which is the independent variable, is measured by financial leverage ratio. Net profit ratio (NPR) is used as the dependent variable for the study. Used data has been analyzed by using regression analysis to find out the links between variables. The output of the study may help to the entrepreneurs, board of directors and policy makers to design better decisions in the debt-equity choice.
\end{abstract}

Keywords: financial structure, net profit ratio, financial leverage ratio, profitability.

\section{INTRODUCTION}

$\mathrm{O}$ ne of the most complex areas of financial decision making is capital structure because of its interrelationship with other financial decisions variables. The main component of the financial decision is represented by profitability and it directly affected by the whole of the capital investment decision, which is the vital one. Commercial companies become profitable organizations. The ultimate goal of commercial companies is to achieve maximum profitability, thus minimizing costs. Finance mainly costed interest on the flow of one of the main components of the cost structure. Most researchers have found a negative link between leverage effect and debt and profitability in their research work. But some authors have presented different opinions, so they have found a positive relationship between the level of profitability and the level of debt in their studies.

At microeconomic level, the direct result of managing multifarious economic resource and their efficient use within investment and financing activities represent the performance index of the firm. This direct result should be based on complex and varied information on the evolution of all types of activities within the company. By analyzing the annual financial statements, a synthetic picture of the company's financial position and its performance can be found. These are therefore the main information sources that allow a qualitative analysis of how resources are used during the process of creating value.

Over the time, the influence of the financial structure on the company's performance level has received special attention in the finance literature. Analyzing the effect of the financial structure on the company's profitability will help us to know the potential problems at the level of finan-

\footnotetext{
$1 \quad$ Bucharest University of Economic Studies, Department of Finance, Romania

2 Bucharest University of Economic Studies, Department of Finance, Romania

3 University of Medicine, Pharmacy, Science and Technology of Târgu Mureș, Romania
} 
cial structure or profitability. Nowadays, trading firms need to run in a complex and competitive environment. Due to the competitive environment of the activity, it is necessary to choose the most suitable capital structure in order to obtain an optimal level of profitability.

The financial structure of the enterprise is represented by a complex and coordinated ensemble of the different sources of finance that the financial manager uses to meet financing needs. In other words, the financial structure can also express the existing ratio between short-term and long-term funding. At enterprise level, the term of financial structure reflects the composition of the capital or the totality of capital components. For this reason, it is called the structure of the capital of the enterprise. When leverage reaches a high share, this leads to an increase in debt, including in turn an increase in bankruptcy or financial distress due to conflicts between equity holders and bondholders. It is very difficult to make distinction between these two sources of agency costs. Accordingly, the financial structure or the capital structure of the enterprise is the sum of the sources of financing involved in forming the capital invested in enterprises. The main criteria that characterize the choice of an optimal financial structure are as follows:

- The leverage effect,

- Financial profitability,

- Lending capacity.

\subsection{Literature Review and Previous Studies}

Song (2005) suggests that the vast majority of the determinant factors of the capital structure suggested by the capital structure theories seems to be relevant for the Swedish market. There are also significant differences between the determinants of long-term and short-term debt. Raheman, Zulfiqar and Mustafa (2007) have indicated that the capital structure of non-financial firms has a significant effect on the profitability of companies listed on the Islamabad Stock Exchange. Dragota and Semenescu (2008) proved that the pecking order theory seemed to be more appropriate for the Romanian capital market, but the signaling theory was not totally rejected.

In their second paper on corporate capital structure, Modigliani and Mill (1963) show that firm value is an increasing function of leverage due to the tax deductibility of interest payments at the corporate level. A negative correlation between leverage and performance, described by the ratio of earnings before interest and tax to total assets, was found in the Chinese firms (Huang and Song, 2006; Chakraborty, 2010). There are also studies such as Ebaid's (2009), where no significant impact was found between capital structure choices and performance. Studies analyzing the impact of financing decisions on performance and profitability usually employ some of the most relevant capital structure determinants.

The trade-off theory as established by Myers (1984) states that the decision on the source of capital for a firm is evaluated based on the various costs and benefits associated with different sources of financing in their quest to obtain an optimal capital structure. The firm is exposed to bankruptcy costs, agency costs and the benefits associated with debt when evaluating the best source of financing. Bankruptcy costs are costs incurred by the firm when the probability of default on financing is greater than zero (Chen, Jung, \& Chen, 2011).

Sina and Matubber (1998) observed that a number of factors such as operational inefficiency, effective credit policy, improper planning and controlling working capital, overhead can lead to the unfavorable position in the industry's managerial performance, profit-making capacity, 
liquidity etc. Choudhury (1993) mentioned that the decline in the company's profitability may be influenced by the reduced use of debt. Because due to lack of adequate finances it has to give up some of the profitable opportunities and vice-versa.

According to Banu (1990), the capital structure of a firm has a direct impact on its profitability. If the enterprise structure is negative, this will have a negative impact on its profitability. In order to avoid this situation, Banu suggested that the financial directors involved should focus on the different aspects of the capital structure.

The agency cost hypothesis-higher leverage, or a lower equity capital ratio is associated with higher profit efficiency, all else being equal and consistent according to Berger, A. N. (2002) findings. When leverage is very high due to the agency cost of outside debt, it is considered that the relationship between performance and leverage may be reversed. In line with the agency theory and their argument that profit efficiency embeds agency costs, profit efficiency is responsible for the ownership structure of the firm.

Larry \& Stulz (1995) illustrated on their study the effect of debt on firms in Ghana which resulted positive significant association between total debt and total assets and return on equity. A study carried out by Murphy (1968), on financing behavior of listed Chinese firms resulted in a conclusion that a negative relationship between profitability and firms leverage exists.

\section{DATA AND METHODOLOGY}

Berger, A. N. (2002) findings are consistent with the agency cost hypothesis-higher leverage, or a lower equity capital ratio is associated with higher profit efficiency, all else being equal. The relationship between performance and leverage may be reversed when leverage is very high due to the agency cost of outside debt. Profit efficiency is responsible to ownership structure of the firm consistent with agency theory and their argument that profit efficiency embeds agency costs.

\subsection{Sample}

The used model is applied to all the companies active in the wholesale of motor vehicle parts and accessories, NACE 4531, with extended financial statements submitted for the entire appraised period were taken into consideration (to eliminate the survivorship effect). Since we need extended format of the financial statements, only companies with turnover above $1 \mathrm{mil}$ EUR have been included.

Table 1: Number distribution of companies

\begin{tabular}{|c|c|c|c|c|c|c|}
\hline Year/Number & 1 - 2,5 MIL EUR & $2,5-5 \mathrm{MIL}$ & $5-10 \mathrm{MIL}$ & $10-50 \mathrm{MIL}$ & $+50 \mathrm{MIL}$ & Total \\
\hline 2008 & 79 & 45 & 17 & 19 & 7 & 167 \\
\hline 2009 & 100 & 47 & 21 & 20 & 8 & 196 \\
\hline 2010 & 106 & 48 & 20 & 21 & 8 & 203 \\
\hline 2011 & 109 & 48 & 24 & 20 & 8 & 209 \\
\hline 2012 & 117 & 50 & 25 & 21 & 8 & 221 \\
\hline 2013 & 120 & 53 & 26 & 21 & 8 & 228 \\
\hline 2014 & 127 & 53 & 27 & 22 & 8 & 237 \\
\hline 2015 & 130 & 55 & 28 & 22 & 8 & 243 \\
\hline 2016 & 131 & 55 & 29 & 22 & 8 & 245 \\
\hline 2017 & 130 & 55 & 29 & 22 & 8 & 244 \\
\hline
\end{tabular}




\subsection{Mode of analysis}

Net Profit Ratio is calculated according to the following formula:

$$
\mathrm{NPR}=\frac{\text { Net profit }}{\text { Revenue }} \times 100
$$

Leverage is calculated according to the following formula:

$$
\mathrm{LeV}=\frac{E B I T}{E B T}
$$

where:

- $\mathbf{E B I T}=$ Earnings before interest and taxes is an indicator of a company's profitability.

- $\mathbf{E B T}=$ A measure of a company's ability to produce income on its operations in a given year.

\subsection{Data source}

The following table illustrates the results of the calculation of Net Profit Ratio and of the calculation of the financial leverage applied to a sample of companies active in the wholesale of motor vehicle parts and accessories (NACE 4531) for the entire period considered (2008-2017).

\begin{tabular}{|c|c|c|c|}
\hline data_bilant & Denumire societate & Lev & NPR \\
\hline 2010-12-31 & PRIMAT GOLD IMPEX SRL & 1.359077974 & 0.021535197 \\
\hline 2011-12-31 & PRIMAT GOLD IMPEX SRL & 1.988214821 & 0.044101936 \\
\hline 2012-12-31 & PRIMAT GOLD IMPEX SRL & 1.459927693 & 0.002603821 \\
\hline 2013-12-31 & PRIMAT GOLD IMPEX SRL & 2.052189262 & 0.001053961 \\
\hline 2009-12-31 & PRIMAT GOLD IMPEX SRL & 0.780877282 & 0.001198473 \\
\hline 2008-12-31 & PRIMAT GOLD IMPEX SRL & 1.391640169 & 0.011579527 \\
\hline 2014-12-31 & PRIMAT GOLD IMPEX SRL & 3.374349394 & 0.001309382 \\
\hline 2015-12-31 & PRIMAT GOLD IMPEX SRL & 3.681678767 & 0.014126057 \\
\hline 2016-12-31 & PRIMAT GOLD IMPEX SRL & 5.00322716 & 0.018056388 \\
\hline 2017-12-31 & PRIMAT GOLD IMPEX SRL & 4.478398744 & 0.009091512 \\
\hline 2010-12-31 & COMAUTOGLOB SRL & 2.071424042 & 0.003595771 \\
\hline 2011-12-31 & COMAUTOGLOB SRL & 2.683757869 & 0 \\
\hline 2012-12-31 & COMAUTOGLOB SRL & 2.62457851 & 0 \\
\hline 2015-12-31 & COMAUTOGLOB SRL & 10.09759494 & 0.015872524 \\
\hline 2014-12-31 & COMAUTOGLOB SRL & 17.68714004 & 0 \\
\hline 2013-12-31 & COMAUTOGLOB SRL & 1.586210985 & 0.024297523 \\
\hline 2009-12-31 & COMAUTOGLOB SRL & 2.017803618 & 0.00851984 \\
\hline 2008-12-31 & COMAUTOGLOB SRL & 2.211307979 & 0.01122444 \\
\hline 2016-12-31 & COMAUTOGLOB SRL & 3.855078258 & 0.048909167 \\
\hline 2017-12-31 & COMAUTOGLOB SRL & 3.423021083 & 0.0360803 \\
\hline 2010-12-31 & COPROT SRL & 0.433561536 & 0.046816875 \\
\hline 2011-12-31 & COPROT SRL & 0.377991645 & 0.062537745 \\
\hline 2012-12-31 & COPROT SRL & 0.531627839 & 0.050074288 \\
\hline
\end{tabular}

Table 2: Calculation of financial leverage and net profit ratio 
High leverage indicates that companies are using debt to fund its assets and operations. Net Profit Ratio indirectly measures how well a company manages its expenses relative to its net sales. A high net profit margin means that a company is able to effectively control its costs and/ or provide goods or services at a price significantly higher than its costs. A low net profit margin means that a company uses an ineffective cost structure and/or poor pricing strategy. For example, „COMAUTOGLOB SRL” illustrates a low net profit ratio for the entire period (2008-2017). On the other hand, „AUTO ABIL SRL” converted 64,4 \% of her sales into profit in 2010.

\subsection{Empirical model}

To analyze the influence of an enterprise's financial structure on its capital, we will use a linear regression model of the form:

$$
\mathrm{Y}=\alpha+\beta^{*} \mathrm{X}+\mathrm{e}
$$

Table 3: The analysis of model variables

\begin{tabular}{|c|c|l|}
\hline $\mathbf{Y}$ & $\frac{\text { Net profit }}{\text { Revenue }} \times \mathbf{1 0 0}$ & $\begin{array}{l}\text { The endogenous variable reflects net profit ratio. It is calculated by deducting } \\
\text { all company expenses from its total revenue. The result of the profit margin } \\
\text { calculation is a percentage }\end{array}$ \\
\hline $\mathbf{X}$ & $\begin{array}{l}\text { The exogenous variable reflects leverage ratio for evaluating financial struc- } \\
\text { ture. A high debt/equity ratio generally indicates that a company has been } \\
\text { aggressive in financing its growth with debt. Typically, a D/E ratio greater } \\
\text { than } 2.0 \text { indicates a risky scenario for an investor. } \\
\text { Negative leverage occurs when a company purchases an investment using } \\
\text { borrowed funds, and the borrowed money has a greater cost, or higher interest } \\
\text { rate, than the return made on the investment. }\end{array}$ \\
\hline
\end{tabular}

\section{RESULTS AND DISCUSSIONS}

Applying the regression equation previously described on the data panel in E-Views, we obtain the following result on which interpretations will be made:




Interpretations: The econometric technique we will use is Panel data regression. In statistics and econometrics, panel data or longitudinal data are multi-dimensional data involving measurements over time. By combining data in two dimensions, panel data gives more data variation, less collinearity and more degrees of freedom. Given the overall concentration of revenues among the largest companies in the overall business environment and the selected list of companies, the sample is divided in five different groups by turnover level, that will further represent the cross-sectional series in the panel data model. The intercept is significantly different from zero to a confidence level of $1 \%$. The slope of the regression curve is different than 0 because of its p-value that is at a level of $0.2 \%$, well below the maximum risk level of $5 \%$. In this case, we rejected the null hypothesis that leads to the conclusion that all slope coefficients are different than zero. The value of Probability for independent variable (0.0027) indicates that the coefficient is significant. Coefficient of independent variable illustrates an inverse relationship between the financial leverage and the Net Profit Ratio, but its influence on the dependency variable is very low due to the value of the coefficient approaching 0. The values for R Squared (0.004) indicates that only $0.4 \%$ of the various Net Profit Ratio is explained by Financial Leverage.

\section{CONCLUSION}

The goal of any business is to maximize assets and minimize costs. In this regard, it is necessary to analyze the weight of each financing state (own funds or debts) in the share of total financing. This study investigated the relationship between financial leverage and net profit margin ratio of the firms that belong to all the companies active in the wholesale of motor vehicle parts and accessories, NACE 4531, with extended financial statements submitted for Romania.

The relationship of these 2 variables was studied using a panel regression model with $2190 \mathrm{ob}-$ servations in total (10-time series for the period 2008-2017). Highly leverage firms have lower profitability and lower leverage firms have higher profitability. The results obtained using panel data are considered to be most relevant due to the large number of observations and on the basis of which we can draw the final conclusions.

The results generated by EViews show that in the context in which we worked; the financial leverage has a negative impact on net profit ratio. Nevertheless, the impact is not significant and the financial leverage only slightly influences the net profit. The results of this study are consistent with the results of previous studies conducted by Ebaid (2009), Huang and Song (2006) and Chakraborty (2010). The results of this study are not matching with the results of previous studies conducted by Larry and Stulz (1995) in which he found a significant positive association between leverage and profitability. He conducted the study in Ghana where the cost of debt is lower than the cost of debt in Romania and he took top twenty companies listed. This could be the reason of contradiction in results of both studies. Because the calculation is complex, other analyzes could lead to different results depending on the calculation method. 


\section{REFERENCES}

[1] Achim, M., Mare, C. and Borlea, S. (2012). A Statistical Model of Financial Risk Bankruptcy Applied for Romanian Manufacturing Industry. Procedia Economics and Finance, 3, pp.132-137.

[2] American Economic Review, 1959.

[3] Baciu Rodica, “THE LEVERAGE EFFECT IMPACT BETWEEN THE ECONOMIC \& FINANCIAL FLOW. CASE STUDY: WHOLESALE OF MOTOR VEHICLE PARTS AND ACCESSORIES (NACE: 4531)" - European Journal of Business and Social Sciences (EJBSS) vol. 6, nr. 02, pg. 99-115, ISSN 2235-767X;

[4] Baciu Rodica, IMPACT OF FINANCIAL STRUCTURE ON ECONOMIC RETURN (ROA - RETURN ON ASSET) - „Proceedings of the Fourth International Scientific Conference - ERAZ 2018”, pg. 99-115

[5] Baciu Rodica, IMPACT OF FINANCIAL STRUCTURE ON ROE (RETURN ON EQUITY)CASE STUDY: WHOLESALE OF MOTOR VEHICLE PARTS AND ACCESSORIES(NACE: 4531), Eurasian Journal of Economics and Finance (EJEF), pg. 175-188, ISBN 2148-0192, conference Internationala, http://eafpeb.org/About.aspx;

[6] Baciu Rodica, The impact of bank credit on financial structure and financial return for the Romanian companies active in car parts distribution, FIBA 2019 International Conference;

[7] Brezeanu, P. - Gestiunea financiară a întreprinderii în economia de piaţă, Fundaţiei „România de mâine” Publishing House, Bucharest, 1999;

[8] Burja V., Todea N., Burja C. - Analiza financiară şi evaluarea societăţilor comerciale, Editura Risoprint, Cluj- Napoca, 2003;

[9] Codarlasu, A. si Ghidesciuc, N, (2008), Applied Econometrics, pp.44-55

[10] Cronbach, L.J. Coefficient Alpha and the Internal Structure of Tests. Psychometrika, 1951.

[11] Dragotă, V., Ciobanu, A., Obreja, L., Dragotă, M. - Management financiar, Vol. II, Economică, Publishing House, Bucureşti, 2003;

[12] Ehrhardt, M.C., Brigham, E.F. Corporate Finance: A Focused Approach, (1st ed.), Mason, Thomson, 2003.

[13] Gavrilaş, Gh. - Impactul costului capitalului asupra procesului dezvoltării economice şi sociale la nivel macroeconomic privit prin prisma politicii economice, RFPC Magazine, no. 4, 2006;

[14] Gemmill, G. Capital Structure and Firm value: A Study of Split-Capital Closed-End funds in the UK, City, 2001.

[15] Georgeta, V. and Georgia, T. (2012). Bankruptcy Prediction Model for Listed Companies in Romania. Journal of Eastern Europe Research in Business \& Economics, pp.1-10.

[16] Hada T. - Finanţele agenţilor economici din România, Editura Intelcredo, Deva, 1999;

[17] Harris, M., Raviv, A. The Theory of Capital Structure. Journal of Finance, 1991.

[18] Higgins, R. C. - Analysis for Financial Management, Eight Edition, Mc-Graw Hill/Irwin, New York, 2007;

[19] Hoanţă, N. - Finanţele firmei, Economică Publishing House, Bucharest, 2003;

[20] Hoanţă, N. - Gestiunea finanţelor firmei, Economică Publishing House, Bucharest, 1999;

[21] Hovakimian, A., Opler, T., Titman, S. (2001). The debt-equity choice. Journal of Financial and Quantitative Analysis, vol.36: 1-24.

[22] Kester, W. C. (1986). Capital and ownership structure: a comparison of United States and Japanese manufacturing corporations. Financial Management, vol.15: 5-16;

[23] Krainer, R. E. - Corporate Finance, Governance and Business Cycles, Theory and International Comparisons, Elsevier, Amsterdam, 2003; 
[24] Kremp, E., Stoess, E., Gerdesmeier, D. (1999). Estimation of a debt function: evidence from French and German firm panel data. Corporate finance in Germany and France. SSRN working paper;

[25] Lambrecht, B. M. (2001). The impact of debt financing on entry and exit in a duopoly. Review of Financial Studies, vol. 14, 765-804.

[26] Leo, T. Almanac of Business and Industrial Financial Ratios, Englewood cliffs, N.J. Prentice - Hall, as quoted by James C. Venhorne. Fundamentals of Financial Management, 1982.

[27] Lucas, D. \& McDonald, R. L. (1990). Equity issues and stock price dynamics. Journal of Finance, vol 37: 121-144;

[28] Mahajan, A. \& Tartaroglu, S. (2008). Equity market timing and capital structure: International evidence. Journal of Banking and Finance, vol. 32: 754-766;

[29] Megginson, W. L. - Corporate Finance Theory, Addison Wesley Educational Publishers Inc., Unites States, 1997;

[30] Miller, M.H. Debt and Tax. Journal of Finance, 1977.

[31] Burja Camelia - Gradul de îndatorare şi performanţa economică, Tribuna economică, nr.3/2006.

[32] Modigliani, F., Miller, M.H. The Cost of Capital Corporation Finance and Theory of Investment.

[33] Phillips, G. M. (1995). Increased debt and industry product markets: an empirical analysis. Journal of Financial Economics, vol. 37: 189-238;

[34] Rajan, R. G. \& Zingales, L. (1995). What do we know about capital structure? Some evidence from International Data. Journal of Finance, vol. 50: 1421-1460.

[35] Ramage, P. - Analyse et diagnostic financier, Editions d Organisation, Paris, 2001;

[36] Sarig, O. H. (1998). The effect of leverage on bargaining with corporation. Financial Review, vol.33: 1-16;

[37] Stroe, R., Bărbuţă-Mişu, N. - Finanţarea şi gestiunea financiară a întreprinderii, Aplicaţii şi studii de caz, Didactică şi Pedagogică Publishing House - R.A., Bucharest, 2008;

[38] Stulz, R. (1990). Managerial discretion and optimal financing policies. Journal of Financial Economics, vol. 26: 3-27;

[39] Tian, S. and Yu, Y. (2017). Financial ratios and bankruptcy predictions: An international evidence. International Review of Economics \& Finance, 51, pp.510-526.

[40] Titman, S. \& Wessels, R. (1988). The determinants of capital structure choice. Journal of Finance, vol. 43: 1-19;

[41] Tulai H. (2004). Pieţe financiare. Editura Casa Cărţii de Ştiinţă. Cluj-Napoca; Korajczyk, R. A. \& Levy, A. (2003). Capital structure choice: macroeconomic conditions and financial constraints. Journal of Financial Economics, vol.68: 75-109.

[42] Turner, J. (2016). Net Operating Working Capital, Capital Budgeting, And Cash Budgets: A Teaching Example. American Journal of Business Education (AJBE), 9(1), pp. 31-62.

[43] Van Horne, J. C. - Financial Management and Policy, Prentice Hall, New Jersey, 2002.

[44] Venhorne, G. Financial Management Policy, Prentice-Hall of India Private Ltd,New Delphi.

[45] Wooldridge, J. (2002). Econometric Analysis of Cross Section and panel Data. Editura MIT Press, Anglia 